\title{
Use of Stream and Dismembered Stream Valleys Now Crossing Wyoming's Northern Laramie Mountains to Test a Recently Proposed Regional Geomorphology Paradigm, USA
}

\author{
Eric Clausen 1 \\ Independent Investigator, Jenkintown, PA, USA \\ Email: eric2clausen@gmail.com
}

How to cite this paper: Clausen, E. (2019) Use of Stream and Dismembered Stream Valleys Now Crossing Wyoming's Northern Laramie Mountains to Test a Recently Proposed Regional Geomorphology Paradigm, USA. Open Journal of Geology, 9, 731-751.

https://doi.org/10.4236/ojg.2019.911087

Received: September 9, 2019

Accepted: September 27, 2019

Published: September 30, 2019

Copyright $\odot 2019$ by author(s) and Scientific Research Publishing Inc. This work is licensed under the Creative Commons Attribution International License (CC BY 4.0). http://creativecommons.org/licenses/by/4.0/

\section{Open Access}

\begin{abstract}
Detailed topographic maps show multiple stream valleys and what are probably dismembered stream valleys that extend completely across Wyoming's northern Laramie Mountains. Several of the most obvious valleys are described with valley origins first explained (or attempted to be explained) from the commonly accepted regional geomorphology paradigm (accepted paradigm) perspective and second from a recently proposed regional geomorphology paradigm (new paradigm) perspective in an effort to determine which of the two paradigms provides the simplest explanations. Accepted paradigm explanations require at least some of the valley erosion to have occurred prior to deposition of Oligocene and Miocene sediments that once covered the northern Laramie Mountains (with some of the exhumed valleys now containing sediment cover remnants). In contrast the fundamentally different new paradigm requires immense south-oriented continental ice sheet melt water floods to have crossed the region as ice sheet related crustal warping raised the region and the Laramie Mountains (and implies sediments now partially filling some of the valleys are probably flood deposited materials). The new paradigm provides simpler explanations for the origins of the valleys now extending completely across the northern Laramie Mountains and also for their related barbed tributaries, truncated side valleys, and drainage route $U$-turns than the accepted paradigm, although the new paradigm also leads to a fundamentally different middle and late Cenozoic regional geologic history than is currently recognized. One paradigm cannot be used to judge a different paradigm, but the paradigms can be compared based on their ability to explain evidence and Occam's Razor can determine which of the two paradigms provides the simplest explanations. New paradigm expla-
\end{abstract}


nations for northern Laramie Mountains valley origins investigated here require fewer assumptions than the accepted paradigm explanations suggesting the new paradigm merits serious future consideration.

\section{Keywords}

Barbed Tributary, Bates Hole, Dugway Rim, Little Medicine Bow River, North Platte River, Through Valley, Wyoming

\section{Introduction}

\subsection{Statement of the Problem}

A recently proposed regional geomorphology paradigm (new paradigm) requires massive south- and southeast-oriented continental ice sheet melt water floods to have flowed across what is today the entire Missouri River drainage basin including what are now high plateau and mountain range areas and is fundamentally different from the commonly accepted regional geomorphology paradigm (accepted paradigm) in which North American continental ice sheets existed at a time when a north-, northeast-, and east-oriented slope would have prevented continental ice sheet melt water floods from reaching most Missouri River drainage basin areas-including the entire state of Wyoming. According to Thomas Kuhn [1], paradigms are sets of rules governing how a scientific community conducts its research and by themselves are neither correct nor incorrect, but are judged on their ability to explain observed evidence. Kuhn suggests that from time to time evidence appears, which the accepted paradigm cannot satisfactorily explain. In such cases Kuhn says the anomalous evidence is dealt with in one of three ways. First, the accepted paradigm eventually explains the problem evidence and the accepted paradigm continues without interruption. Second, the unexplainable evidence is put on the shelf for future consideration. Third, the anomalous evidence leads to a new paradigm and a battle over which paradigm should be used.

When faced with the choice between two fundamentally different paradigms a scientific community can also apply Occam's Razor to determine which of two competing paradigms provides the simplest explanations. Occam's Razor in science, according to Anderson [2] suggests "What can be done with fewer [assumptions] is done in vain with more". Stream and dismembered stream valleys extending completely across Wyoming's northern Laramie Mountain represent known, but so far poorly explained evidence. Topographic maps depict the valleys and associated features such as barbed tributaries, drainage route U-turns, truncated side valleys, and deep canyons that cut across hogback ridges and high mountain areas, yet the published literature does not address how the valleys and their associated drainage features originated. Whether that failure is due to the accepted paradigm's inability to explain the evidence or to geomorphologists 
giving other sets of evidence a higher priority is unknown. However, these unusual valleys provide an opportunity to describe previously unexplained landform features, to attempt to explain the valley origins from the perspective of two fundamentally different regional geomorphology paradigms, and to apply Occam's Razor to determine which of the two competing paradigms requires the fewest number of assumptions.

\subsection{Geographic Setting}

Figure 1 provides modified United States Geological Survey (USGS) National Map website imagery showing the northern Laramie Mountains region. The city of Casper, Wyoming is to the north of Casper Mountain, which forms the northwest end of the northwest-to-southeast oriented northern Laramie Range. To the south of Figure 1 southeast corner the Laramie Range is oriented in a north-to-south direction and is a northern extension of the north-to-south oriented Colorado Front Range. In simplified terms the Laramie Mountains can be described as a broad anticlinal uplift where steeply dipping Paleozoic and Mesozoic sedimentary rocks and Precambrian igneous and metamorphic rocks are now exposed. To the north of Figure 1 map area is the Powder River Basin (between the Bighorn Mountains and the Black Hills) and to the south is the Laramie Basin (between the Laramie Mountains and the Medicine Bow Mountains). The principal drainage route seen in Figure 1 is the North Platte River, which originates in northcentral Colorado and flows in a northwest and north direction to the Laramie Range northwest end where the river has cut a 300-meter deep canyon and then turns in an east and southeast direction to flow along the Laramie Mountains northeast flank and into Nebraska where it joins the northeast-oriented South Platte River to form Nebraska's east-oriented Platte River (flowing to the Missouri River with the water ultimately reaching the Gulf of Mexico). In Figure 1 northwest corner are northeast-oriented South Fork Powder River headwaters with the Powder River flowing in a north direction through the Powder River Basin and in Montana joining the northeast-oriented Yellowstone River (which at the North Dakota border joins the Missouri River with the water today eventually reaching the Gulf of Mexico).

All northern Laramie Mountains drainage flows to the north- and then eastand southeast-oriented North Platte River, although some water flows in west directions to north-oriented North Platte River segments while other drainage flows in north and northeast directions to east- and southeast-oriented North Platte River segments. The Little Medicine Bow River drains in a south direction before joining the west-oriented Medicine Bow River (not shown), which flows in a west direction to join the north-oriented North Platte River while the North Laramie River begins in the Laramie Mountains as a southwest-oriented stream (flowing toward Little Medicine Bow River headwaters) before turning in an east direction to flow across the Laramie Mountains with its water eventually reaching the southeast-oriented North Platte River. What may be dismembered stream 
valleys link southwest-oriented tributaries (not shown) to northwest-oriented Bates Creek with northeast-oriented Muddy Creek and also with north-oriented Deer Creek while Deer Creek and Box Elder Creek have south-oriented headwaters flowing toward the Little Medicine Bow River, but once south and west of the mountains those streams turn in north directions to flow through deep canyons to reach the east- and southeast-oriented North Platte River. A deep through valley links the La Prele Creek and Little Medicine Bow River headwaters and La Bonte Creek begins in a dismembered valley near North Laramie River headwaters and flows in a northeast direction across the Laramie Mountains while the North Laramie River flows in a south direction before turning in an east direction to flow across the Laramie Mountains. Streams do not normally flow across mountain ranges, yet in Figure 1 map area multiple stream and dismembered stream valleys extend completely across the northern Laramie Mountains.

\subsection{Previous Work}

When comparing paradigms three types of previous work are important. First is paradigm neutral previous work describing, but not interpreting observed evidence. For determining how well a paradigm explains drainage system origins detailed topographic maps provide the most useful paradigm neutral previous work. The study reported here used topographic maps of the northern Laramie Mountains region available at the United States Geological Survey (USGS) National

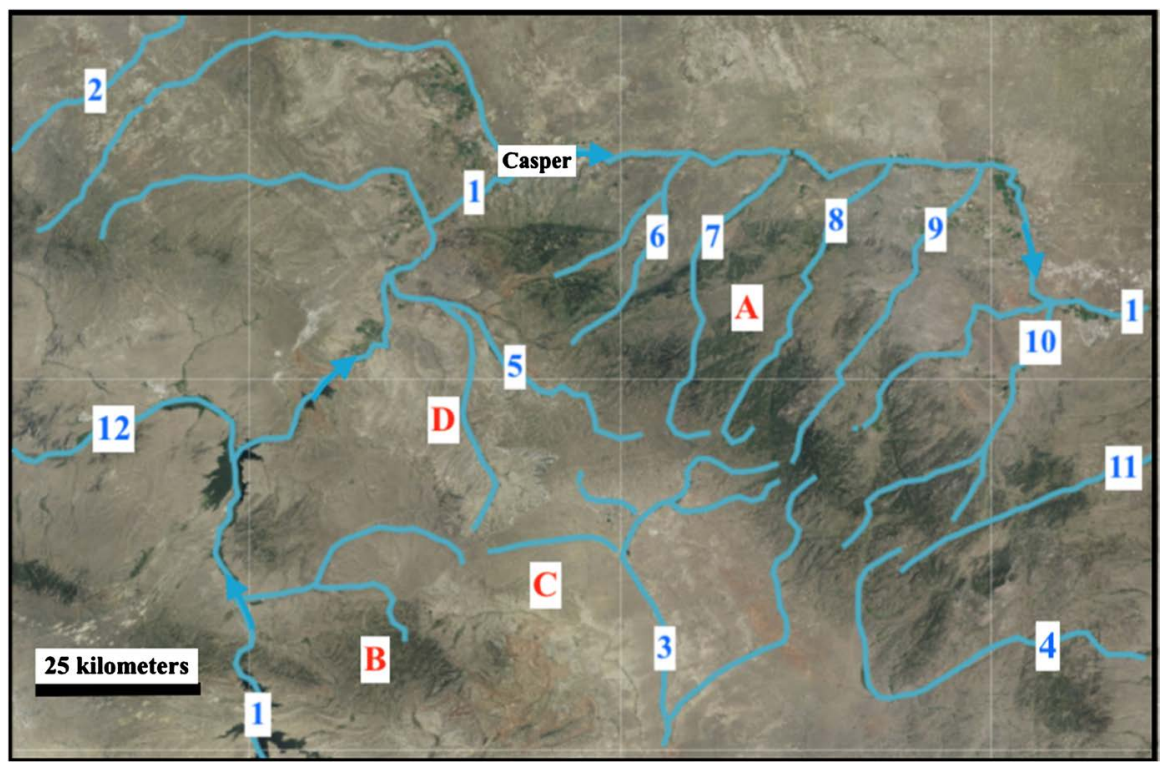

Figure 1. Modified USGS National Map website imagery showing the northern Laramie Mountains area. Drainage routes are: 1-North Platte River, 2-South Fork Powder River, 3-Little Medicine Bow River, 4-North Laramie River, 5-Bates Creek, 6-Muddy Creek, 7-Deer Creek, 8-Box Elder Creek, 9-La Prele Creek, 10-La Bonte Creek, 11-Horseshoe Creek, and 12-Sweetwater River. Other identified geographic features are: A-Laramie Range, B-Shirley Mountains, C-Shirley Basin, and D-Bates Hole. Arrows show North Platte River flow directions. 
Map website. Also useful in determining drainage system origins are geologic maps, which depict where rock units and geologic structures exist, although geologic maps can also include paradigm influenced interpretations. Geologic maps referred to in the study reported here include the Hunter et al. Geologic Map of the Casper Quadrangle [3], the Jones and Gregory Preliminary Geological Map of the Shirley Basin [4], the McLaughlin and Ver Ploeg Geologic Map of the Douglas Quadrangle [5], and the Love et al. Geologic Map of the Torrington Quadrangle [6].

Previous work done according to accepted paradigm rules represents the second category and interprets the Wyoming drainage system to have been developed on a sedimentary cover that filled intermontane basins and partially buried mountain ranges. For example, Blackstone [7] describes how some specific northern Laramie Mountain wind gaps originated by saying, "The wind gaps are due to the superposition of streams upon the pre-Oligocene topography and later capture by headward eroding tributaries. The tributaries are able to extend their valleys headward more rapidly than the main stream because of the soft Tertiary sediments in which they head". Evanoff [8] describes middle Tertiary fossiliferous rocks in 14 northern Laramie Mountain paleo-valleys by saying these "sequences include a basal very coarse conglomerate, middle tuffaceous mudrocks, and [an] upper conglomerate". Evanoff argues the lack of deformation precludes "post-Eocene block uplift as a source of modern topographic relief [and that] the regionally widespread low-relief subsummit surface was developed during the Miocene, and is not part of the late Eocene unconformity". Discussing the Tertiary sediments that covered the pre-Oligocene topography Lillegraven and Ostresh [9] state "Because of the extensive early Oligocene infillings of Wyoming's basins, a basic eastwardly grained drainage pattern... was established. ... By late Chadronian time, Wyoming's landscape was one of considerable monotony, dominated by vast savannah shrublands with distantly and heavily eroded remnants of Laramide uplifts. ...until about the middle of the Miocene.... Conditions then shifted during an interval of several million years that was characterized by alternate cutting and filling.... Finally, approximately the past 10 million years reflect the dominance of massive erosion..., exhuming an essentially Eocene topography".

In a literature review Mears [10] summarizes some accepted paradigm previous work by saying, "At the climax of the Laramide orogeny, during the latest Paleocene and earliest Eocene, the relief of the mountains exceeded that of the present... [during the mid-Eocene] the crests of the mountains were lowered by erosion and the mountain valleys and broad intermontane basins were filled. The basin deposits were partially excavated during a widespread late Eocene interval of regional erosion that preceded the onset of renewed basin filling in the latest Eocene.... The rising level of Oligocene and then Miocene deposits eventually lapped across the lower segments of the crystalline-cored uplands that had been eroded down to broad subsummit surfaces surmounted by residual hills and 
peaks... broad regional uplift began to raise the mountains to their present-day elevations. The exhumation of the present broad basin floors and adjacent mountain valleys began in mid-Miocene time...". More recently McMillan et al. [11] report "the timing and causes of the elevation gain and incision in the [Rocky Mountain] region are unclear" and Fan et al. [12] describe work supporting "a hypothesis that the steep elevation gradient between the central Rockies and the western Great Plains has existed as a major topographic feature since at least earliest Oligocene time with the mean elevation contrast comparable to the modern topography".

Also supporting such accepted paradigm interpretations are paleogeographic map reconstructions by Galloway et al. [13] showing Oligocene and Miocene east-oriented drainage systems to the east of the Laramie Mountains and the north-south continental divide a short distance to the north of the northern Laramie Mountains. From the accepted paradigm perspective, the north-south continental divide was located just to the north of the Laramie Mountains from about Eocene to Quaternary time when continental ice sheets blocked pre-glacial north-oriented rivers to form the present-day Missouri River. This pre-glacial north-oriented drainage system is known in the geologic literature as the Bell River drainage system (see [14]) and is supported by abandoned valleys extending northward from where north-oriented tributaries now join the Montana and North and South Dakota Missouri River. Glacial deposits partially fill those abandoned valleys and are used to support the pre-glacial age determination. White [15] argued that continental ice sheets should have destroyed all evidence of any pre-glacial valleys especially in the easily-eroded northern plains region bedrock. However, numerous workers including Gravenor [16] and Sugden [17] rejected White's alternative deep erosion by continental ice sheets hypothesis and the accepted paradigm continues to interpret those abandoned valleys as pre-glacial in age.

In contrast the new paradigm's defining rule requires south- and southeast-oriented floods of continental ice sheet melt water to have flowed across what is today the entire Missouri River drainage basin including what are now high plateau areas and mountain ranges. That rule (which from the accepted paradigm perspective is impossible) forces recognition of at least one continental ice sheet that deeply eroded the underlying bedrock and that was also thick and heavy enough to cause significant crustal warping so as to create a deep "hole" and to raise adjoining plateau areas and mountain ranges while large melt water floods flowed across them. The new paradigm also leads to a middle and late Cenozoic Rocky Mountain and northern plains region geologic and glacial history that is fundamentally different from the accepted paradigm determined regional geologic and glacial history. While not working from the new paradigm perspective Love [18] and Steidtmann et al. [19] suggest south-oriented rivers did flow during Eocene and Oligocene time to the west of the northern Laramie Mountains. Working from the new paradigm perspective Clausen [20] [21] in- 
terprets Wyoming topographic map evidence (located to the west of the north Laramie Mountains) to show that large south-oriented floods did flow across the Bighorn River-Wind River drainage divide between Wind River Canyon and the Bighorn Mountains and also across the Wind River-Sweetwater River drainage divide. In those papers the present-day North American east-west continental divide (in Wyoming) is described as being a segment of the ice sheet created deep "hole" southwest rim.

In addition, from the new paradigm perspective Clausen [22] uses topographic maps evidence to show how large floods eroded an anastomosing complex of Laramie Range canyons (in the area to the south of Figure 1 southeast corner). Clausen [23] also interprets topographic map evidence to show how massive southeast-oriented floods flowed across the eastern Powder River Basin's Belle Fourche River-Cheyenne River drainage divide. Clausen [24] [25] further uses topographic maps to show how what the accepted paradigm considers to be pre-glacial north-oriented Bell River drainage system valleys eroded headward from deep "hole" space being opened up as an ice-walled and bedrock-floored canyon network chopped the decaying thick ice sheet into detached and semidetached ice masses. Deep "hole" space opened up by the ice-walled and bedrock-floored canyons enabled huge southeast-oriented melt water floods to be diverted to flow through the ice sheet's canyon network across the decaying ice sheet's floor in north directions and to create what in the accepted paradigm is the pre-glacial Bell River drainage system. This floodwater diversion from the Gulf of Mexico to the North Atlantic and Arctic Oceans changed climatic conditions and created a second and much thinner continental ice sheet.

\section{Research Method}

This study was first done as part of the author's much larger Missouri River drainage basin landform origins research project during the 1999-2001 time period to determine how the Missouri River drainage basin originated when detailed topographic map mosaics covering the entire Missouri River drainage basin were systematically studied. Results were fundamentally different from anything in the geologic literature and to be understood required large mosaics of detailed topographic maps. The large study was repeated during the 2011-2013 time period using National Geographic TOPO software and topographic maps with more than 500 research notes in blog format being posted at geomorphologyresearch.com. Subcomponents of that 2011-2013 project, such as the study reported here, are now being repeated for publication purposes.

The investigation reported here began by initially scanning topographic maps found at the United States Geological Survey (USGS) National Map website to identify stream or what may be dismembered stream valleys that extend completely across the northern Laramie Mountains. Deer and Box Elder Creeks were identified as flowing in south directions towards the south-oriented Little Medicine Bow River and then making U-turns before flowing completely across the 
Laramie Mountains to reach the east- and southeast-oriented North Platte River. Northeast-oriented La Prele Creek, which also flows completely across the Laramie Mountains, is linked by a well-defined through (or dry) valley with the south-oriented Little Medicine Bow River. Muddy Creek was identified as being linked by through valleys with southwest-oriented Bates Creek tributaries and La Bonte Creek headwaters were identified as flowing in a north-to-south oriented dismembered stream valley that extends completely across the Laramie Mountains, which is also linked by through valleys with south-oriented Little Medicine Bow River tributaries. Deer and Box Elder Creeks were noted to have not only south-oriented headwaters but also south-oriented barbed tributaries and truncated valleys are to the north of their south-oriented headwaters and barbed tributaries. Geologic maps were next studied and most, but not all, of the identified valleys were noted to cross geologic units and structures. Finally, an effort was made (as described below) to explain the observed map evidence first from the accepted paradigm perspective and second from the new paradigm perspective.

\section{Results}

\subsection{Muddy Creek-Bates Creek through Valleys}

Northeast-oriented Muddy Creek is the westernmost of several north- and northeast-oriented streams flowing in valleys that extend completely across the northwest-to-southeast oriented northern Laramie Mountains. Muddy Creek does not flow all the way across the mountains, but is formed by northeast-oriented streams that are linked by dry valleys with southwest-oriented streams draining to northwest-oriented Bates Creek. The northernmost dry valley is more than 150 meters deep and links (with a floor elevation at the drainage divide of 2214 meters) east-northeast oriented Clear Fork Muddy Creek with west- and southwest-oriented Big Red Creek (flowing to Bates Creek). Further to the southeast another deep dry valley (floor elevation 2280 meters) links northeast-oriented Otter Creek and southwest- and northwest-oriented Corral Creek and still another deep dry valley (floor elevation of 2284 meters) links northeast-oriented Smith Creek with southwest-and northwest-oriented Sheep Creek. The northwest-oriented Sheep Creek segment flows through a 200-meter deep water gap to reach Corral Creek. Rocky Gap (floor elevation 2200 meters) is a 100-meter deep wind gap linking the southwest-oriented Corral Creek segment with northeast-oriented Smith Creek. Two kilometers to the east of Rocky Gap an unnamed and deep wind gap (floor elevation 2270 meters) links a north-oriented Smith Creek tributary with east-northeast oriented West Fork Deer Creek (flowing to north-oriented Deer Creek), which is linked by a dry valley (floor elevation 2284 meters) with south-southwest oriented Kerfoot Creek flowing to Bates Creek. Detailed topographic maps show many other shallower but similar dry valleys, water gaps, and wind gaps that are too numerous to list.

From the accepted paradigm perspective, the dry valleys, water gaps, and wind gaps linking the Bates and Muddy Creek drainage basins are difficult to explain. 
Water eroded these features with the dry valleys indicating water probably flowed along multiple routes across the Casper Mountain southeast flank while today the North Platte River flows to the west and north of Casper Mountain. Some dry valley segments are located between hogback ridges and might represent where two headward eroding valleys met, although such an explanation does not explain valley segments cut across the hogback ridges or the remarkable similarity of the dry valley floor elevations. A possible accepted paradigm interpretation explaining a few southwest-to-northeast oriented dry valleys is before northern Laramie Mountains uplift the North Platte River flowed in a northeast direction along what is now the Casper Mountain southeast flank and was joined by several northeast-oriented tributaries, although such an interpretation does not explain how the northwest-oriented Bates Creek route originated or why and how the present-day North Platte River route was established and only explains a few valleys. Some unexplained features can be explained if middle Tertiary sediments covered what is now an exhumed landscape, although the Hunter et al. [3] map shows middle Tertiary sediments only present in some Sheep Creek and Kerfoot Creek valley areas and the question can be asked as to why middle Tertiary sediment remnants are missing from upland regions and the other stream and dry valleys?

In contrast the new paradigm explains the same features by immense south-oriented floods that flowed in large complexes of diverging and converging channels crossing what at that time was a rising Laramie Mountains area with the North Platte valley eroding headward along the northern Laramie Mountains northeast flank and then around Casper Mountain to capture, behead, and reverse those south-oriented flood flow channels. Baker [26] describes how massive floods spilled across Washington Channeled Scabland region drainage divides to erode a complex of diverging and converging valleys similar to those crossing the Muddy Creek-Bates Creek drainage divide. Prior to North Platte River valley headward erosion Casper Mountain uplift forced some south-oriented flood flow to move in a southwest direction along the present-day northeast-oriented North Platte River alignment (west of Casper Mountain) and once around Casper Mountain some floodwaters diverged in a southeast direction along what is today the northwest-oriented Bates Creek alignment to converge with south- and southwest-oriented flood flow that was being forced to flow around the Casper Mountain uplift's eastern flank with the combined flow then moving into what is now the south-oriented Little Medicine Bow River drainage basin. Regional and Laramie Mountains uplift also enabled deeper flood flow channels to capture water from shallower channels and eventually North Platte River valley headward erosion beheaded and reversed the few remaining south-oriented flood flow channels to create in sequence from east to west the modern-day north-and northeast-oriented North Platte tributaries seen in Figure 1. Continued North Platte River valley headward erosion around Casper Mountain next beheaded and reversed the southwest-oriented flood flow 
channel (on the present-day northeast-oriented North Platte River alignment), which in turn beheaded and reversed the southeast-oriented flood flow channel on the Bates Creek alignment to create the northwest-oriented Bates Creek drainage system.

\subsection{Deer Creek-Bates Creek and Deer Creek-Little Medicine Bow River Linkages}

Deer Creek (seen in Figure 2 and Figure 3) and several tributaries begin as south-oriented streams that after leaving the mountains make U-turns and converge to flow in a north direction completely across the northern Laramie Mountains before turning in a northeast direction to reach the North Platte River. Upper Deer Creek Canyon (seen in Figure 3) is more than 500 meters deep and the Hunter et al. [3] map shows it cut in Archean granitic intrusive rocks while the downstream Lower Deer Creek Canyon (further to the north) is more than 400 meters deep and is cut across Archean gneissic granite, Paleozoic strata, and the Muddy Mountain Fault Zone. In addition to the Deer Creek U-turn south-oriented streams join north-oriented Deer Creek as barbed tributaries. Immediately to the south of where south-oriented Deer Creek headwaters make their U-turn is Dugway Rim, a low ridge atop a 200-meter high or higher south-facing escarpment which serves as the Deer Creek-Little Medicine Bow River drainage divide. Several low points along Dugway Rim suggest water once flowed from the Deer Creek drainage basin into the Little Medicine Bow River drainage basin. The Jones and Gregory [4] map shows Dugway Rim to be the boundary between Tertiary Upper White River Formation (north) and Tertiary

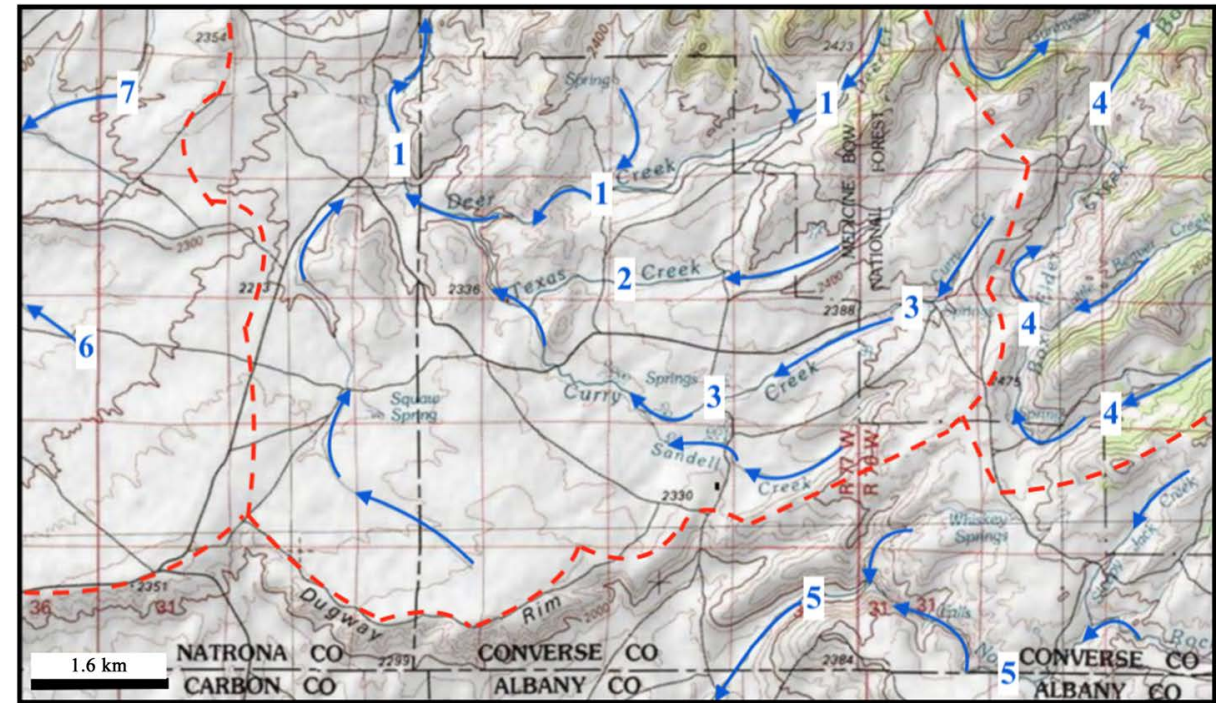

Figure 2. Modified topographic map from the USGS National Map website showing the Deer and Box Elder Creek headwaters area. Dashed red lines show major drainage divides. Blue letters identify drainage routes: 1-Deer Creek, 2-Texas Creek, 3-Curry Creek, 4-Box Elder Creek, 5-North Fork Little Medicine Bow River, 6-Bates Creek, 7-East Fork Bates Creek. Contour interval is 20 meters. Figure 2 southeast corner overlaps Figure 4 northwest corner. 
Lower White River Formation (south). Immediately to the west of the Deer Creek U-turn, and between Dugway Rim and the Laramie Mountains, are west-northwest oriented Bates Creek headwaters flowing on Upper White River Formation bedrock. Dry valleys suggest water once flowed between the Deer Creek U-turn and northwest-oriented Bates Creek. Further to the northwest a previously mentioned dry valley suggests water once flowed between northeast-oriented West Fork Deer Creek and south-southwest-oriented Kerfoot Creek (now flowing to Bates Creek).

Explaining Deer Creek drainage features from the accepted paradigm perspective is difficult if not impossible. Downcutting by a north-oriented North Platte River tributary through middle Tertiary sediments covering the northern Laramie Mountains might explain the north-oriented Upper and Lower Deer Creek Canyons, but does not explain how such a north-oriented stream could capture south-oriented streams just to the north of the south-facing Dugway Rim escarpment or the dry valleys linking the Deer Creek drainage basin with the south-oriented Little Medicine Bow River and the northwest-oriented Bates Creek drainage basins. Further, while geologic maps show (Oligocene or Miocene) Upper White River Formation conglomerate in the Deer Creek headwaters area and (Upper Miocene) Ogallala Formation in the area between the two deep Deer Creek canyons those sediments are missing from most other Deer Creek drainage basin areas. If the White River Formation and/or Ogallala Formations did once cover the northern Laramie Mountains (as many accepted paradigm interpretations suggest) remnants of those Oligocene and Miocene sediments should be more widespread in the higher elevation areas than the geologic maps show. In addition, topographic maps show south-oriented Deer Creek headwaters and Deer Creek tributaries make U-turns and strongly suggest water once flowed between the north-oriented Deer Creek drainage basin and the northwest-oriented Bates Creek and the south-oriented Little Medicine Bow River drainage basins, or vice versus, although those U-turns and linkages with adjacent drainage basins are almost impossible to explain if Oligocene and $\mathrm{Mi}$ ocene sediments had buried the northern Laramie Mountains.

Deer Creek drainage system features are easier to explain from the new paradigm perspective. Prior to North Platte River valley headward erosion diverging and converging south-oriented flood flow channels crossed the rising north Laramie Mountains and eroded the south-facing Dugway Rim escarpment headward (or in a north direction). As ice sheet related crustal warping raised the region and the mountains the south-oriented melt water floods were funneled into fewer and fewer channels with the present-day north-oriented Deer Creek valley being one of the last surviving south-oriented channels. An example of how the Deer Creek valley captured south-oriented flow is seen in Figure 3 where the southwest-oriented Horse Creek valley truncates a north-to-south oriented abandoned valley leading to the south-oriented Deer Creek headwaters indicating that south-oriented flood flow to the Deer Creek headwaters was captured 
and diverted into a deeper flood flow channel on the present-day north-oriented Deer Creek alignment. North Platte River valley headward erosion combined with regional and northern Laramie Mountains uplift eventually resulted in the beheading and reversal of flood flow in the south-oriented Deer Creek channel to create the north-oriented Deer Creek drainage route and the Deer Creek headwaters U-turns and barbed tributaries. North Platte River valley headward erosion subsequently beheaded and reversed southeast-oriented flood flow on the Bates Creek alignment (which may have been first captured by the Deer Creek flow reversal) to create the northwest-oriented Bates Creek drainage basin and the Deer Creek-Bates Creek drainage divide. While not the focus of this paper assuming large volumes of floodwaters water were in and around the Shirley Basin area the new paradigm perspective also explains how the Bates Creek flow reversal probably eroded the northwest-oriented Bates Hole escarpment-surrounded basin.

\subsection{Box Elder Creek-Deer Creek and Box Elder Creek-Little Medicine Bow River Linkages}

Box Elder Creek (seen in Figure 2 and Figure 3) begins as a southwest-oriented stream flowing toward the Deer Creek headwaters and a Little Medicine Bow River tributary and then near Dugway Rim makes a U-turn to flow in a northeast direction (with short north-oriented segments) to reach the North Platte River. Most of the 300-meter deep (or deeper) Box Elder Creek valley and of the Box Elder Creek tributary valleys seen in Figure 3 are shown on the McLaughlin and Ver Ploeg [5] map to be eroded in granite with upper Miocene Ogallala sediments located in some valley segments. The East Fork Box Elder Creek flows in a 300-meter deep (or deeper) north-oriented valley and to the south of Figure 3 is linked by a short 200-meter deep (or deeper) dry valley with a southwest-oriented Little Medicine Bow River tributary indicating water once flowed between the Box Elder Creek and Little Medicine Bow River drainage basins. The northeast-oriented Box Elder Creek valley is wider and straighter than the north-oriented Deer Creek and East Fork Box Elder Creek valleys and is joined by south-oriented barbed tributaries. One barbed tributary, Buck Creek, begins as a northeast-oriented stream before turning in a southeast direction to join northeast-oriented Box Elder Creek. Northeast-oriented Buck Creek headwaters are located in a remarkably straight southwest-to-northeast oriented through valley cut in granite bedrock and which is now drained on opposite ends by southwest-oriented Horse Creek (flowing to Deer Creek) and northeast-oriented Snowshoe Creek (flowing to Box Elder Creek). A dismembered stream or river probably once flowed in that through valley. To the northeast of Figure $3 \mathrm{mid}$ Tertiary Ogallala and White River sediments are located in some valley segments as Box Elder Creek flows across Archean granite and gneiss and Paleozoic hogback ridges before crossing Cretaceous and early Tertiary bedrock areas near the North Platte River. Geologic maps suggest the regional drainage pattern developed independently of any mapped geologic features. 


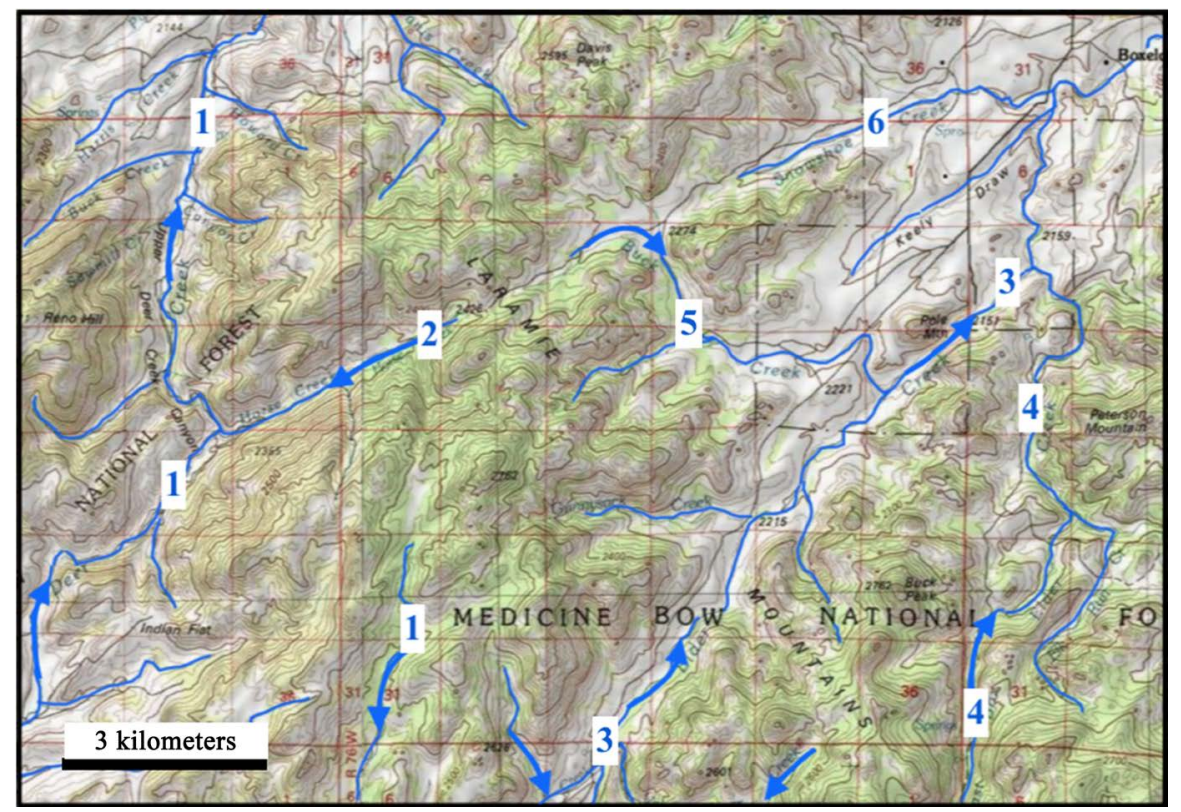

Figure 3. Modified topographic map from USGS National Map website showing Deer and Box Elder Creek routes across the Laramie Mountains. Numbers identify streams as follows: 1-Deer Creek (note the south-oriented Deer Creek headwaters to the east of the north-oriented Deer Creek route), 2-Horse Creek, 3-Box Elder Creek, 4-East Fork Box Elder Creek, 5-Buck Creek, and 6-Snowshoe Creek. Contour interval is 20 meters. Figure 3 is to the north of Figure 2.

The accepted paradigm perspective also makes the Box Elder drainage system with its multiple deep valleys cutting across high elevation Laramie Range crystalline core bedrock, barbed tributaries and U-turns, linkages with the Little Medicine Bow River and Deer Creek drainage systems, and related Horse-Buck-Snowshoe Creek through valley extremely difficult if not impossible to explain. Middle Tertiary sediments are located in some Box Elder Creek drainage system valleys and assuming those sediments once covered the northern Laramie Mountains (as some previous investigators imply) it may be possible to explain the Box Elder and East Fork Box Elder Creek valleys, but that explanation does not explain the barbed tributaries, the U-turns, the linkages with the Little Medicine Bow River, or the Horse-Buck-Snowshoe Creek through valley. Further, the middle Tertiary sediments are mapped in valley and other low elevation areas and not in the higher elevation regions, which would be expected if the present-day Box Elder Creek drainage system had originated on such a sedimentary cover. Another possible accepted paradigm explanation is some of the hard-to-explain Box Elder Creek drainage system features pre-date the middle Tertiary sediment cover (as some previous investigators suggest), although that explanation only pushes the problem of how those drainage features developed further back into geologic time.

From the new paradigm perspective the north-oriented Box Elder Creek and the East Fork Box Elder Creek valleys probably originated when diverging south-oriented flood flow channels crossed the rising Laramie Mountains and 
flood waters moved to what is today the south-oriented Little Medicine Bow River drainage basin. What are now south-oriented barbed tributaries originated as south-oriented flow channels that converged with south-oriented flood flow on what is now the northeast-oriented Box Elder Creek alignment. Regional and Laramie Mountains uplift combined with North Platte River headward erosion eventually caused a flood flow reversal that explains the Box Elder Creek U-turns and barbed tributaries. The Horse-Buck-Snowshoe Creek through valley originated before that flood flow reversal as a southwest-oriented flood flow channel that diverged from the Box Elder Creek flood flow channel and then converged with the south-oriented Deer Creek flood flow channel. Note in Figure 3 how the southwest-oriented Horse Creek valley truncates an abandoned high elevation valley leading to the south-oriented Deer Creek headwaters valley and also how the southeast-oriented Buck Creek segment is linked by a high-level abandoned valley with a northwest-oriented Deer Creek tributary valley. These and other high-elevation abandoned valleys are what would be expected as regional and Laramie Mountains uplift caused the diverging and converging flood flow channel complex to evolve with deeper channels capturing flood flow from shallower channels with the water at the north ends of the beheaded flood flow channels reversing flow directions to move toward the deeper beheading valleys, which explains the modern-day northeast-oriented Buck Creek headwaters, Snowshoe Creek, and other north-oriented Box Elder Creek tributaries).

\subsection{La Prele Creek-Little Medicine Bow River Linkages}

La Prele Creek (headwaters seen in Figure 4) flows in a northeast direction completely across the northern Laramie Mountains including through a 400-meter deep or deeper upper canyon carved in Archean age granite. Downstream from that upper canyon the McLaughlin and Ver Ploeg map [11] shows La Prele Creek to flow across areas covered by Oligocene and Upper Eocene White River Group sediments and through a lower canyon cut across Paleozoic hogback ridges. La Prele Creek does not begin as south-oriented stream, but a 200-meter deep southwest-to-northeast oriented through valley seen at location "A" in Figure 4 links La Prele Creek headwaters with southwest-oriented North Fork Little Medicine Bow River headwaters. The through valley suggests water once flowed between what are now the north-oriented La Prele Creek and the south-oriented Little Medicine Bow River drainage basins. Love et al. [6] show the La Prele Creek-North Fork Little Medicine Bow River through valley to be cut in Archean granite with lower Miocene rocks sometimes mapped as Arikaree Formation present on the through valley floor. While geologic maps show Oligocene and Miocene sediments in other nearby valleys such sediments are not shown in higher elevation areas surrounding the La Prele Creek upper canyon. Barbed tributaries are not as noticeable in the La Prele Creek drainage basin as in the Deer and Box Elder Creek drainage basins although Roaring Fork begins 


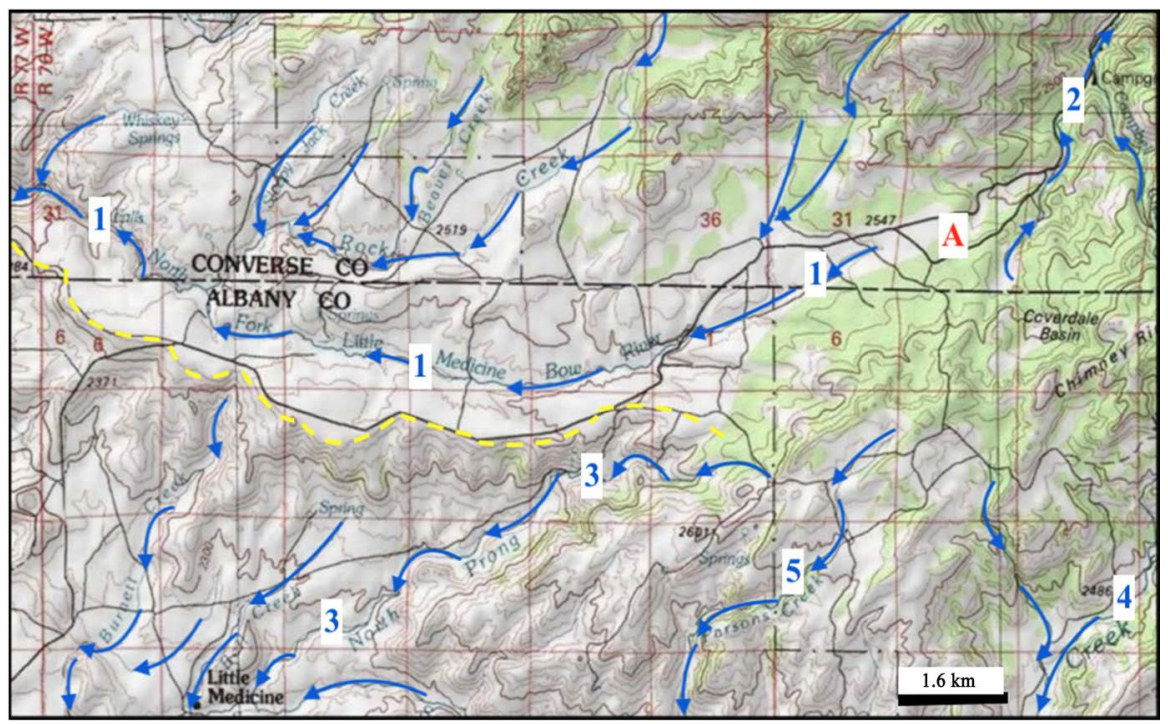

Figure 4. Modified topographic map from USGS National Map website showing the La Prele Creek-North Fork Little Medicine Bow through valley (at red letter "A"). Arrows show flow directions and the yellow dashed line shows the Dugway Rim escarpment eastern extension. Blue numbers identify streams: 1-North Fork Little Medicine Bow River, 2-La Prele Creek, 3-North Prong Little Medicine Bow River, 4-Sheep Creek (flowing to Little Medicine Bow River), 5-Parsons Creek (flowing to South Prong Little Medicine Bow River). Figure 4 northwest corner overlaps Figure 2 southeast corner.

as a south-oriented stream before making a U-turn to join La Prele Creek as a northeast-oriented stream and further downstream (or to the north) several southeast-oriented streams flowing on White River Group sediments join northeast-oriented La Prele Creek as barbed tributaries just south of where La Prele Creek enters its 200-meter deep lower canyon (that cuts across a semi-isolated hogback ridge area composed of Paleozoic, Mesozoic, and Precambrian rock units) before flowing across another region of mapped White River Group sediments to reach the North Platte River.

White River sediments surrounding the semi-isolated hogback ridges (where the La Prele Creek lower canyon is located) support accepted paradigm interpretations that present-day drainage routes originated on a cover of Oligocene and Miocene sediments. However, that explanation runs into trouble just upstream from the lower canyon where three southeast-oriented barbed tributaries join northeast-oriented La Prele Creek. Explaining those barbed tributaries from the accepted paradigm perspective is difficult especially if the La Prele Creek drainage route originated on the sediment cover. Further upstream geologic maps do not show middle Tertiary sediments in the higher elevation Archean granite areas surrounding the La Prele Creek upper canyon, an observation that requires accepted paradigm explanations to also explain how the hypothesized middle Tertiary sediment cover was removed from higher elevation areas and not from lower elevation areas. Finally, there is no good accepted paradigm explanation for the La Prele Creek-North Fork Little Medicine Bow River through valley. It is a water eroded valley and water once flowed through it in one direc- 
tion or the other, but the accepted paradigm provides no reason why water from the south-oriented Little Medicine Bow River drainage basin would flow across the Laramie Mountains or why what is today the north-oriented La Prele Creek drainage basin would have once drained in a south direction to the Little Medicine Bow River drainage basin.

The three barbed tributaries joining La Prele Creek to the south of the La Prele Creek lower canyon are easily explained from the new paradigm perspective by the convergence of south-oriented flood flow channels prior to the La Prele Creek flow reversal. The flow reversal was caused by regional and Laramie Mountains uplift that also enabled the deep North Platte River valley to erode headward along the northeast flank of the rising Laramie Mountains. The lack of middle Tertiary sediments on higher elevation areas and the origin of the La Prele Creek-North Fork Little Medicine Bow River through valley are not problems from the new paradigm perspective because the La Prele Creek upper canyon is explained by massive and prolonged south-oriented melt water floods that flowed across the rising Laramie Mountains to reach what is today the south-oriented Little Medicine Bow River drainage basin and the middle Tertiary sediments can be explained as possible flood transported and deposited materials.

\subsection{La Bonte Creek-Little Medicine Bow River and La Bonte Creek-North Laramie River Linkages}

La Bonte Creek (headwaters seen in Figure 5) flows in a narrow and twisting north-oriented canyon before turning in an east-northeast and then northeast direction in La Bonte Canyon (not shown) to eventually reach the southeast-oriented North Platte River. The La Bonte Creek-North Laramie River drainage divide crosses Fortymile Flat (at location A in Figure 5), which is in a north-to-south oriented through valley that extends approximately 60 kilometers from the La Prele Creek lower canyon (north) to the Laramie Basin margin (south). Today the south-oriented North Laramie River drains the through valley south half, north-oriented La Bonte Creek headwaters and east-oriented West Fork La Bonte headwaters drain a through valley middle section, northand northeast-oriented Wagon Hound Creek drains the through valley segment between the La Bonte Creek drainage basin and the La Prele Creek drainage basin, and north-oriented La Prele Creek tributaries and La Prele Creek drain the through valley northernmost segment. The Love et al. [6] map shows the relatively straight north-to-south oriented through valley cuts across Archean age granite and amphibolite and is partially filled with Oligocene White River Formation from Fortymile Flat southward while to the north of the La Bonte Creek drainage basin undifferentiated Oligocene and Miocene sediments partially fill the valley. As seen in Figure 5 dry valleys at locations B and C link La Bonte Creek tributaries with streams flowing to south-oriented Sheep Creek and the Little Medicine Bow River. Further to the south at Mule Creek Pass (not shown) 


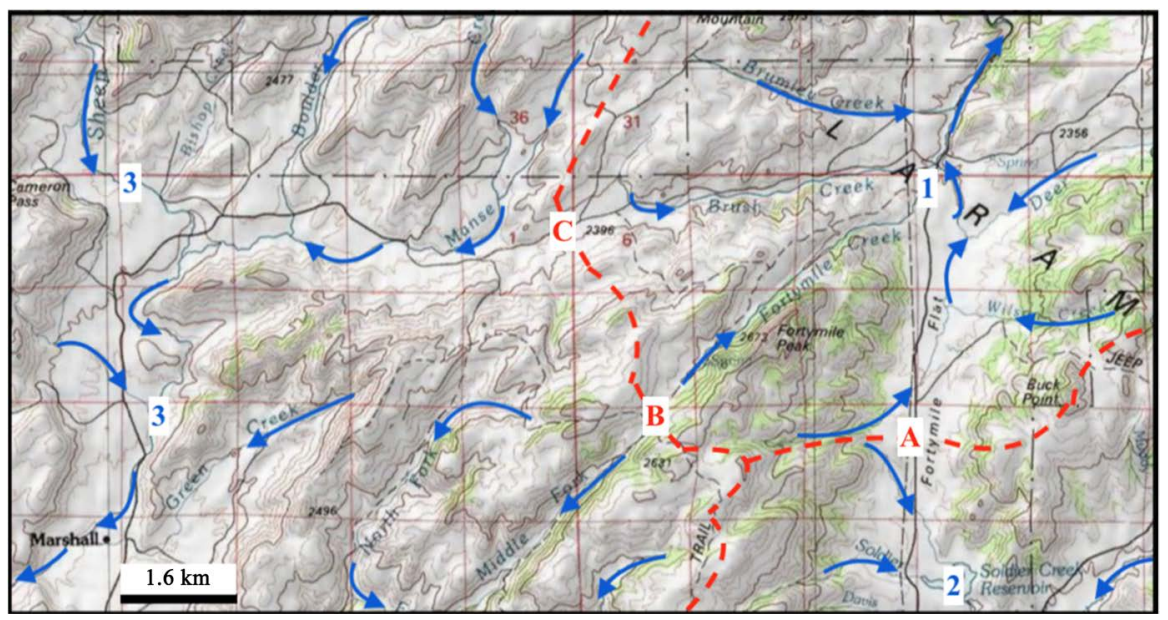

Figure 5. Modified topographic map from USGS National Map website. Blue numbers identify streams: 1-Fortymile Creek flowing to La Bonte Creek, 2-Soldier Creek flowing to North Laramie River, 3-Sheep Creek flowing to Little Medicine Bow River. Red dashed lines indicate major drainage divides. The contour interval is 20 meters.

the south-oriented North Laramie River valley truncates the west- and south-oriented Mule Creek valley (draining to Sheep Creek).

While the accepted paradigm explains sediments filling the through valley northern and southern segments there is no good accepted paradigm interpretation for why a north-to-south oriented through valley cuts across the northern Laramie Mountains unless the valley was eroded along a north-to-south geologic feature (e.g. a fault line or other zone of weakness). However, geologic maps show no such geologic feature. Further, the accepted paradigm provides no good explanation for the dry valleys seen in Figure 5 at locations $B$ and $C$ and for the (unseen) truncated Mule Creek valley (at Mule Creek Pass). On the other hand, the new paradigm explains the north-to-south oriented through valley as a south-oriented flood flow channel that Laramie Mountains uplift dismembered. Likewise, the dry valleys at locations B and C and the truncated Mule Creek valley are explained by diverging west- and southwest-oriented flood flow channels that led to what is today the south-oriented Little Medicine Bow River drainage basin and the Mule Creek valley was truncated when headward erosion of the deeper east-oriented North Laramie River valley across the Laramie Mountains (see Figure 1) captured south-oriented flood flow in what is today the dismembered north-to-south oriented through valley, and then eroded headward in a north direction.

\section{Discussion}

From the accepted paradigm perspective valleys now containing Oligocene and Miocene sediments were eroded prior to any North American continental ice sheets. In other words, from the accepted paradigm perspective the new paradigm explanations are impossible and should be rejected. However, Kuhn [1] states that one paradigm cannot be used to judge a fundamentally different pa- 
radigm and competing paradigms need to be evaluated based on their ability to explain evidence. When compared on their ability to explain the valleys and other drainage features described here the new paradigm without question provided the most complete and simplest explanations. The question then arises how does the new paradigm explain the presence of mapped Oligocene and Miocene sediments in what the new paradigm explanations interpret to have been continental ice sheet melt water eroded valleys? While a detailed answer is beyond the scope of this paper the logical new paradigm explanation is massive south-oriented meltwater floods (that were subsequently reversed to flow in north and northeast directions as the North Platte River valley eroded headward along the Laramie Mountains northeast flank) transported and deposited the Oligocene and Miocene sediments now found in the northern Laramie Mountain valleys. Such an interpretation is supported by sediment compositions that include coarse-grained conglomerates found in many of those deposits. For example, Evanoff [8] states "A very coarse conglomerate containing [granite] clasts up to $8 \mathrm{~m}$ in maximum diameter occurs at the base of the western paleovalley fills. The conglomerate is typically exposed at the mouths of the paleovalleys and extends as fan-shaped bodies away from the mountain front". Large volumes of water are required to move such large clasts.

It should be noted the two fundamentally different paradigms lead to completely different regional geologic histories where the words Eocene, Oligocene, Miocene, Pliocene, and Quaternary, while referring to the same sediments, have different meanings and may not even refer to the same absolute time intervals. The accepted paradigm requires long periods of absolute time to raise mountains, erode those mountains while filling the adjacent intermontane basins and burying the eroded mountains, before again raising the mountains, and then at least partially excavating the intermontane basins. The new paradigm does not require long periods of absolute time to erode high mountains and fill and then excavate the intermontane basins. Instead, sediments now filling the northern Laramie Mountains valleys are flood transported and deposited materials and the new paradigm requires much shorter periods of absolute time to raise the Laramie Mountains while immense south-oriented floods flowed across them and a mechanism to explain why the Laramie Mountains uplift occurred as massive south-oriented floods flowed across the region. That mechanism could simply be a continental ice sheet that was thick and heavy enough to raise mountain ranges and plateau areas as gigantic melt water floods flowed from it.

\section{Conclusion}

Paradigms as described by Kuhn [1] by themselves are neither correct nor incorrect and one paradigm cannot be used to judge another paradigm. Instead paradigms are judged based on their ability to explain evidence. When comparing fundamentally different paradigms, Occam's Razor suggests the paradigm providing the simplest and most complete explanations should be preferred. 
This study compared the ability of a recently proposed regional geomorphology paradigm and of the commonly accepted regional geomorphology paradigm to explain easily observed (on detailed topographic maps) stream and other erosional valleys that now extend completely across Wyoming's northern Laramie Mountains. If just the erosional features are considered the new paradigm provides simpler and more complete explanations and the new paradigm should be preferred. However, if sediments contained in some of the eroded valleys are also considered the two paradigms lead to fundamentally different interpretations of middle and late Cenozoic geologic history and further work is needed to compare how the two competing paradigms explain other sets of easily observed geomorphic and geologic evidence.

\section{Acknowledgements}

During the mid 1960s Arthur Strahler, then at Columbia University, and Brainerd Mears, Jr., then at the University of Wyoming introduced the author to unsolved drainage history problems. Preliminary work related to this research project was done while employed as a Minot State University faculty member where library staff, other faculty members, and students provided access to the needed topographic map collections.

\section{Conflicts of Interest}

The author declares no conflicts of interest regarding the publication of this paper.

\section{References}

[1] Kuhn, T.S. (1970) The Structure of Scientific Revolutions. Second Edition, University of Chicago Press, Chicago, $210 \mathrm{p}$.

[2] Anderson, D.L. (2002) Occam's Razor: Simplicity, Complexity, and Global Dynamics. Proceeding of the American Philosophical Society, 146, 56-76.

[3] Hunter, J., Ver Ploeg, A.J. and Boyd, C.S. (2005) Geologic Map of Casper 30' x 60' Quadrangle. Wyoming State Geological Survey, Map Series MS-65, Scale 1:100,000.

[4] Jones, N.R. and Gregory, R.W. (2011) Preliminary Geologic Map of the Shirley Ba$\sin 30^{\prime} \times 60^{\prime}$ Quadrangle, Carbon, Natrona, Albany, and Converse Counties, Wyoming. Wyoming State Geological Survey, Open File Report 11-8, Scale 1:100,000. https://doi.org/10.3133/i539

[5] McLaughlin, J.F. and Ver Ploeg, A.J. (2008) Geologic Map of the Douglas 30' x 60' Quadrangle. Wyoming State Geological Survey, Map Series MS-83, Scale 1:100,000.

[6] Love, J.D., Christensen, A.C. and Sever, C.K. (1980) Geologic Map of the Torrington 1 Degree x 2 Degree Quadrangle, Southeastern Wyoming and Western Nebraska. U.S. Geo-Logical Survey, Miscellaneous Field Studies Map MF-1184, Scale 1:250,000. https://doi.org/10.3133/mf1184

[7] Blackstone, D.L. (1946) Origin of Certain Wind in the Laramie Mountains, Wyoming. The Journal of Geology, 54, 252-259. https://doi.org/10.1086/625349

[8] Evanoff, E. (1990) Early Oligocene Paleovalleys in Southern and Central Wyoming: Evidence of High Local Relief on the Late Eocene Unconformity. Geology, 18, 
443-446. https://doi.org/10.1130/0091-7613(1990)018<0443:EOPISA>2.3.CO;2

[9] Lillegraven, J.A. and Ostresh, L.J. (1988) Evolution of Wyoming's Early Cenozoic Topography and Drainage Patterns. National Geographic Research, 4, 303-327.

[10] Mears, B. (1993) Geomorphic History of Wyoming and High-Level Erosion Surfaces. In: Snoke, A.W., et al., Eds., Geology of Wyoming, Geological Survey Wyoming, Memoir 5, 608-626.

[11] McMillan, M.E., Heller, P.L. and Wing, S.L. (2006) History and Causes of Post-Laramide Relief in the Rocky Mountain Orogenic Plateau. Geological Society of America Bulletin, 118, 393-405. https://doi.org/10.1130/B25712.1

[12] Fan, M., Heller, P., Allen, S.D. and Hough, B.G. (2014) Middle Cenozoic Uplift and Concomitant Drying in the Central Rocky Mountains and Adjacent Great Plains. Geology, 42, 547-550. https://doi.org/10.1130/G35444.1

[13] Galloway, W.E., Whiteaker, T.L. and Ganey-Curry, P. (2011) History of North American Drainage Evolution, Sediment Yield, and Accumulation in the Gulf of Mexico Basin. Geosphere, 7, 938-973. https://doi.org/10.1130/GES00647.1

[14] Jackson, L. (2018) The Paleo-Bell River: North America's Vanished Amazon. Earth, 63, 74-81.

[15] White, W.A. (1972) Deep Erosion by Continental Ice Sheets. Geological Society of America Bulletin, 83, 1037-1056. https://doi.org/10.1130/0016-7606(1972)83[1037:DEBCIS]2.0.CO;2

[16] Gravenor, C.P. (1975) Erosion by Continental Ice Sheets. American Journal of Science, 275, 594-604. https://doi.org/10.2475/ajs.275.5.594

[17] Sugden, D.E. (1976) A Case against Deep Erosion of Shields by Continental Ice Sheets. Geology, 4, 580-582. https://doi.org/10.1130/0091-7613(1976)4<580:ACADEO >2.0.CO;2

[18] Love, J.D. (1970) Cenozoic Geology of the Granite Mountains Area, Central Wyoming. United States Geological Survey Professional Paper 495-C, 154 p. https://doi.org/10.3133/pp495C

[19] Steidtmann, J.R., Middleton, L.T. and Shuster, M.W. (1989) Post-Laramide (Oligocene) Uplift in the Wind River Range, Wyoming. Geology, 17, 38-41. https://doi.org/10.1130/0091-7613(1989)017<0038:PLOUIT>2.3.CO;2

[20] Clausen, E. (2019) Topographic Map Interpretation of the Bighorn River-Wind River Drainage Divide Area Located East of Wyoming' Wind River Canyon. Universal Journal of Geoscience, 7, 56-67. https://doi.org/10.13189/ujg.2019.070202

[21] Clausen, E. (2019) Use of Topographic Map Evidence to Test a Recently Proposed Regional Geomorphology Paradigm: Wind River-Sweetwater River Drainage Divide Area, Central Wyoming, USA. Open Journal of Geology, 9, 404-423. https://doi.org/10.4236/ojg.2019.98027

[22] Clausen, E. (2018) Topographic Analysis of Laramie Range Bedrock-Walled Canyon Complex and the Goshen Hole Escarpment-Surrounded Basin, Albany and Platte Counties, Southeast Wyoming, USA. Open Journal of Geology, 8, 33-55. https://doi.org/10.4236/ojg.2018.81003

[23] Clausen, E. (2018) Belle Fourche River-Cheyenne River Drainage Divide Area in the Wyoming Powder River Basin Analyzed by Topographic Map Interpretation Methods, USA. Journal of Geography and Geology, 10, 1-16.

https://doi.org/10.5539/jgg.v10n2p1 http://www.ccsenet.org/journal/index.php/jgg/article/view/73048

[24] Clausen, E. (2018) Deep Erosion by Continental Ice Sheets: A Northern Missouri 
River Drainage Basin Perspective: North America. Current Research in Geoscience, 8, 27-38. https://doi.org/10.3844/ajgsp.2018.27.38

[25] Clausen, E. (2019) How a Fundamentally Different and New Glacial History Paradigm Explains North American Prairie Region Erosional Escarpments and Drainage Patterns. Earth Science Research, 8, 23-34.

[26] Baker, V.R. (1981) Large-Scale Erosional and Depositional Features of the Channel Scabland. In: Baker, V.R., Ed., Catastrophic Flooding. The Origin of the Channeled Scabland, Dowden, Hutchinson and Ross, Inc., Stroudsburg, 276-310. https://doi.org/10.1130/abs/2016RM-275904 